\title{
Equity and the Urban University: Introduction to the Chicago Conference Issue
}

\author{
Beatriz Gonzalez and Howard Rosing
}

This 2018 CUMU Annual Conference issue of Metropolitan Universities journal (MUJ) highlights efforts by universities and scholars seeking to engage directly with issues of equity in cities. Reflecting on the conference theme, Partnering for Equity, the City of Chicago offered arguably one of the most sobering and rich contexts for discussing the role of higher education in promoting equity. A 2017 study found the cost of lost income to Chicago's regional economy due to racial segregation exceeded $\$ 4$ billion (Urban Institute, 2017, pg. IX). This same study noted an estimated 83,000 college degrees never attained because of racial segregation (Urban Institute, 2017, pg. 40). Chicago, like many urban areas, presents the most pressing opportunities and challenges for uncovering and addressing issues of equity.

As reflected in the conference presentations and speeches, one of the most important changes in higher education is the growing recognition that social change begins on and around the campus. Paulo Freire posited this view nearly 40 years ago in Pedagogy of the Oppressed, naming education a political act. To fully realize this transformative power of higher education, universities must partner across institutions and sectors to reveal and address critical issues of equity. This is the focus of the work shared at the 2018 CUMU Annual Conference.

\section{In this Issue}

The articles in this 2018 CUMU Annual Conference edition of Metropolitan Universities journal epitomize the work of metropolitan and urban colleges and universities in cooperating with communities to address mutual challenges and goals towards social justice. Lipman's conference keynote address sets the stage for this edition by provoking frank reflection on how higher education institutions can contribute to the development of educational policy that dismantles gross inequities based on race and class.

Tackling Grand Challenges: Community Engagement and Collective Impact in Public ProblemSolving reviews approaches to university-led grand challenge initiatives. Such initiatives have grown in presence in recent years, particularly because of the Obama Administration 2012 call to engage private and public sectors, including higher education, in joint national and global problem solving. Tackling Grand Challenges points to an approach that incorporates principles developed both within and outside the Academy: community-engaged scholarship, which brings meaning and relevance to learning and collective impact, and attends to essential structural issues relevant in the community. By bridging these worlds, the authors posit that grand challenge initiatives are more likely to be mutually beneficial, attuned to complexity, and thus more effective. The authors describe the example of the University of Denver, as an institution, which has used the frameworks in the implementation and organization of its interdisciplinary, publicly engaged work.

With a focused look at one partnership between a civic organization and a public university, Alignment through Community: The Case of a Metropolitan University and the Greater Oklahoma City Hispanic Chamber of Commerce reveals how goal alignment between partners 
can spur greater effectiveness for both entities. This case example, based on the work of the University of Central Oklahoma (UCO) and the local Hispanic Chamber of Commerce (HC), demonstrates that such alignment can lead to extramural funding, transformative learning practices, and professional growth, strengthening workforce and city development. The alignment begins with the explicit match of UCO's academic mission as a metropolitan university with the HC's purpose. The joint clarity on their shared goals strongly anchored the partnership for both parties with the necessary engagement of senior leadership, the investment of resources, and even organizational restructuring for cross-entity effectiveness. While describing what is clearly a substantive endeavor, Alignment through Community demonstrates the deep return on investment that such efforts have.

In examining the mutually beneficial, reciprocal relationship between a university and civic leaders, Civic Leadership Education at the University of Chicago reinforces the efficacy of assetbased approaches to community development. Civic Leadership describes not only the transformation of the University's understanding of civic education, but also of its sense of responsibility for fostering it in the city of Chicago. The mutual respect across partners as cocreators of knowledge evident in the program led to a more rigorous and authentic curriculum more likely to lead to necessary change in Chicago. This article explores the University's investment in civic studies, the concept of civic leadership from the practitioner perspective, and questions of equity and inclusion, involving all in the civic-leadership development program.

While civic education and leadership development provide an important on-campus tool for engaging students in community development, college access is and will remain a critical component of creating equity and inclusion in cities. In Achieving College Readiness through a Dual Enrollment Course: "Strategies for Success," Cram and Béjar outline an approach for universities to collaborate with the k-12 system and to work intentionally with students to attain the skills needed to be successful at the university. Florida International University (FIU) employed a dual enrollment course, Strategies for Success, evaluating and adjusting it over multiple years to determine its progress and impact. Through mentoring and coaching interventions, the course and program show promise toward providing the support and the needed academic and contextual foundation for low-income and underrepresented students to succeed in college.

Urban universities can also be an important resource for increasing equity in access to health knowledge. In their article, Urban Partnerships to Address Health Literacy in High Need Populations, Keller et al. describe how Marquette University collaborated with local nonprofits to implement and evaluate an evidence-supported health literacy program for low-income African American residents of Milwaukee. The project illustrates the role universities can play in illuminating the importance of health literacy training to improve the health and wellbeing of historically marginalized populations. The project provides evidence of a successful collaboration between a university and community-based organizations that can contribute to improving equity in health outcomes by local populations impacted by structural racism.

In Community Engagement vs. Racial Equity: Can Community Engagement Work be Racially Equitable? Telles offers a striking picture of the lack of attention to racial equity within community engagement in higher education. She argues that for institutions to be truly transformative in their urban settings, they should explicitly incorporate racial equity as a 
component within engagement initiatives. Furthermore, the gap in literature in relation to racial equity in higher education community engagement provides an opportunity for scholars to engage in empirical research regarding racial equity in relation to organizational structures, staffing and programs. Echoing sentiments from Pauline Lipman's conference keynote, Telles concludes, "failing to address issues of racial equity within higher education community engagement initiatives may facilitate transforming into engaged institutions that continue to operate as racially exclusionary spaces."

We close this issue with reflections by Emily Janke, the inaugural recipient of the Barbara A. Holland Scholar-Administrator Award. In Scholar-Administrators as Change Agents, Janke explores the definition of scholar-administrator and how it looks in practice. She argues that through the integration of scholarship with administration, one can both ask and answer critical questions facing our institutions and communities. This in turn enhances our understanding of how to change institutional practices to fully realize the transformative power of higher education for our students and their families and our communities. Because of this, Janke calls the field to "better recognize, prepare and support scholar-administrators so that they can do what they do so well: serve as key change agents in and of higher education, and to lead boldly into a yet-to-be defined future." 


\section{References}

Darder, A. (2018). Critical leadership for social justice: Unveiling the dirty little secret of power and privilege. In P. McLaren \& S. SooHoo (Eds.), The radical imagine-nation: Public pedagogy and praxis (pp. 41-73). New York, NY: Peter Lang.

Freire, P. (1971). Pedagogy of the oppressed. New York, NY: Seabury Press.

Garcia, G.A. (2017). Decolonizing Hispanic serving institutions: A framework for organizing. Journal of Hispanic Higher Education, 17, 132-147. https://doi.org/10.1177/1538192717734289

Giroux, H.A. (2011). Neoliberalism and the death of the social state: Remembering Walter Benjamin's angel of history. Social Identities, 17, 587-601.

https://doi.org/10.1080/13504630.2011.587310

Mason, Maryann (2019). Adolescent Firearm Homicide in Chicago 2013-2017:

Young Black Males at High Risk. Retrieved from the Injury Prevention and Research Center Smith Child Health Research, Outreach and Advocacy Center, Stanley Manne Children's Research Institute https://news.wttw.com/sites/default/files/article/fileattachments/FINAL\%20DATA\%20BRIEF\%20\%20IVDRS\%20Adolescent\%20Firearm\%20Ho mocide\%20in\%20Chicago\%202013\%20to\%202017\%20Young\%20Black\%20Males\%20at \%20 High\%20Risk\%20\%281\%29.pdf

Urban Institute (2017). The Cost of Segregation: National Trends and the Case of Chicago, 1990-2010. Retrieved from https://www.urban.org/sites/default/files/publication/89201/the_cost_of_segregation_final_0.pdf

Wealth Distribution in the United States in 2016. (2019). Retrieved from https://www.statista.com/statistics/203961/wealth-distribution-for-the-us/ 


\section{Author Information}

*Beatriz Gonzalez, Ph.D.

Chief Diversity Officer \& Vice Provost

University of La Verne

Office of Diversity and Inclusivity

Founders Hall

Room 106

La Verne, CA 91750

Telephone: (909) 448-4512

Email: bgonzalez@laverne.edu

Dr. Gonzalez is Chief Diversity Officer \& Vice Provost at University of La Verne. Gonzalez came to the University of La Verne in August 2013 as associate provost for faculty affairs. She was appointed to her current titles in April 2016, broadening her responsibilities to include retention of students, faculty, and staff with a focus on diversity, equity, and inclusion.

Howard Rosing, Ph.D.

Executive Director

Irwin W. Stearns Center for Community-Based Service Learning

DePaul University

2233 N. Kenmore Avenue

Chicago, IL 60614

Telephone: (773) 325-7457

Email: hrosing@depaul.edu

Dr. Rosing is the Executive Director of the Steans Center where he oversees the work of Academic Service Learning and the Egan Office for Urban Education and Community Partnerships and supports DePaul's partnership with the Asset-Based Community Development Institute housed at the Center. He works with faculty to develop scholarship on service-learning and community-based research as pedagogies. Dr. Rosing also serves as a faculty member in Community Service Studies and an affiliate faculty member in Geography, Sustainable Urban Development (MASUD) and Community Psychology and co-directs MASUD. He has taught and developed numerous service learning courses including Community Food Systems and Geography, Food and Justice, which serve as required courses in DePaul's Minor in Food Studies. Dr. Rosing is a cultural anthropologist whose research focuses on urban food access, economic restructuring, community food systems, and food justice movements in Chicago and the Dominican Republic.

*Corresponding author 